\title{
Chemical composition, vitamins and minerals of a new cultivar of lychee (Litchi chinensis cv. Tailandes) grown in Brazil
}

Thalita Azevedo CABraL, Leandro de Morais CARdoso*, Helena Maria PinHeIRo-SANT'ANA

Lab. Vitam. Anal., Dep. Nutr. Health, Fed. Univ. Viçosa, PH Rolfs Ave., Viçosa, Minas Gerais, 36571-000, Brazil,

leandro.cardoso@ufv.br
${ }^{*}$ Correspondence and reprints

Received 8 November 2013 Accepted 26 March 2014

Fruits, 2014, vol. 69, p. 425-434 (C) 2014 Cirad/EDP Sciences All rights reserved DOI: 10.1051/fruits/2014031 www.fruits-journal.org

RESUMEN ESPAÑOL, p. 434
Chemical composition, vitamins and minerals of a new cultivar of lychee (Litchi chinensis cv. Tailandes) grown in Brazil.

Abstract - Introduction. Different cultivars of lychee are produced all around the world and to date no information has been published on the nutritional value of $\mathrm{cv}$. Tailandes, which is a new lychee cultivar introduced into Brazil and other tropical countries. Our study performed a pioneering evaluation of the physical and chemical characteristics, carotenoids, vitamins, and minerals in pulp of fruit of this cultivar. Materials and methods. Titratable acidity was determined by volumetric neutralization, $\mathrm{pH}$ by potentiometry, soluble solids by refractometry, moisture by gravimetry after oven drying, ash by calcination in a muffle furnace, proteins by the micro-Kjeldahl method, dietary fibers by the gravimetric non-enzymatic method and lipids by gravimetry after extraction in ethyl ether. Vitamin C (ascorbic and dehydroascorbic acids) and carotenoids $(\alpha$-carotene, $\beta$-carotene, $\beta$-cryptoxanthin and lycopene) were analyzed by high-performance liquid chromatography (HPLC) with diode array detection, vitamin $\mathrm{E}(\alpha-, \beta-, \gamma$ - and $\delta$-tocopherols and tocotrienols) was analyzed by HPLC with fluorescence detection, and fourteen minerals were analyzed by atomic absorption spectrometry in inductively coupled plasma. Results and discussion. The lychee cv. Tailandes showed high pulp yield $(59.0 \%)$, moisture $\left(80.7 \mathrm{mg} \cdot 100 \mathrm{~g}^{-1}\right)$ and dietary fiber $\left(2.2 \mathrm{~g} \cdot 100 \mathrm{~g}^{-1}\right)$, and a low total energy value $\left(70.2 \mathrm{kcal} \cdot 100 \mathrm{~g}^{-1}\right)$. It presented no carotenoids, but was an excellent source of vitamin $\mathrm{C}$ (34.7 mg.100 g $\mathrm{g}^{-1}$ ). The total vitamin E content was $117.0 \mathrm{~g} \cdot 100 \mathrm{~g}^{-1}$. Pulp of lychee cv. Tailandes was shown to be a source of iron $\left(0.86 \mathrm{mg} \cdot 100 \mathrm{~g} \mathrm{~g}^{-1}\right)$ and magnesium $\left(12.90 \mathrm{mg} \cdot 100 \mathrm{~g}^{-1}\right)$, a good source of copper $\left(0.12 \mathrm{mg} \cdot 100 \mathrm{~g}^{-1}\right)$ and an excellent source of potassium $\left(1067.33 \mathrm{mg} \cdot 100 \mathrm{~g} \mathrm{~g}^{-1}\right)$. Conclusion. The lychee cv. Tailandes showed high pulp yield and low total energy. The pulp is a source of dietary fiber, vitamin $\mathrm{C}$, iron, magnesium, copper and potassium.

Brazil / Litchi chinensis / fruits / physicochemical properties / proximate composition / mineral content / vitamin C / vitamin E

Composition chimique, vitamines et éléments minéraux dans le fruit d'un nouveau cultivar de litchi (Litchi chinensis cv. Tailandes) exploité au Brésil.

Résumé - Introduction. Différents cultivars de litchi sont produits dans le monde mais aucune information n'a été publiée jusqu'à présent sur la valeur nutritive du cv. Tailandes, nouveau cultivar de litchi introduit au Brésil et dans d'autres pays tropicaux. Notre étude a permis d'évaluer pour la première fois les caractéristiques physiques et chimiques, et les teneurs en caroténoïdes, vitamines et minéraux de la pulpe du fruit de ce cultivar. Matériel et méthodes. L'acidité titrable a été déterminée par neutralisation volumétrique, le $\mathrm{pH}$ par potentiométrie, les solides solubles par réfractométrie, l'humidité par gravimétrie après séchage au four, la teneur en cendres par calcination dans un four à moufle, les protéines par la méthode micro-Kjeldahl, les fibres alimentaires par la méthode non-enzymatique gravimétrique et les lipides par gravimétrie après extraction à l'éther éthylique. La vitamine $\mathrm{C}$ (acides ascorbique et déhydroascorbique) et les caroténoïdes ( $\alpha$-carotène, $\beta$-carotène, $\beta$-cryptoxanthine et lycopène) ont été analysés par chromatographie liquide à haute performance (HPLC), la vitamine $\mathrm{E}(\alpha-, \beta-, \gamma-$ et $\delta$-tocophérols et tocotriénols) a été analysée par HPLC avec détection de fluorescence, et quatorze minéraux ont été analysés par spectrométrie. Résultats et discussion. Les fruits de litchi cV. Tailandes ont présenté un rendement élevé en pulpe (59,0\%), en humidité $\left(80,7 \mathrm{mg} \cdot 100 \mathrm{~g} \mathrm{~g}^{-1}\right)$ et fibres alimentaires $\left(2,2 \mathrm{~g} \cdot 100 \mathrm{~g}^{-1}\right)$; ils ont montré une faible valeur énergétique totale $\left(70,2 \mathrm{kcal} \cdot 100 \mathrm{~g}^{-1}\right)$. Ces fruits n'ont pas révélé de caroténoïdes, mais ils sont une excellente source de vitamine C $\left(34,7 \mathrm{mg} \cdot 100 \mathrm{~g}^{-1}\right)$. La teneur totale en vitamine E a été de $117 \mathrm{~g} \cdot 100 \mathrm{~g}^{-1}$. Les fruits du litchi cv. Tailandes se révèlent être une source de fer $\left(0,86 \mathrm{mg}_{\left.100 \mathrm{~g}^{-1}\right)}\right.$ et de magnésium $\left(12,90 \mathrm{mg} \cdot 100 \mathrm{~g}^{-1}\right)$, une bonne source de cuivre $\left(0,12 \mathrm{mg} \cdot 100 \mathrm{~g}^{-1}\right)$ et une excellente source du potassium $\left(1067,33 \mathrm{mg} \cdot 100 \mathrm{~g}^{-1}\right)$. Conclusion. Les fruits du litchi cv. Tailandes ont montré un rendement élevé en pulpe et une faible valeur énergétique totale. La pulpe est une source de fibres alimentaires, de vitamine $C$, de fer, de magnésium, de cuivre et de potassium.

Brésil / Litchi chinensis / fruits / propriété physicochimique / composition globale / teneur en éléments minéraux / vitamine C / vitamine $\mathrm{E}$ 


\section{Introduction}

The lychee (Litchi chinensis Sonn.) is a nonclimacteric subtropical fruit that has a high commercial value. This fruit has been widely cultivated for many years in countries of Africa and Asia, especially in China $[1,2]$. Lychee pulp is sweet, juicy and of great nutritional value and, due to these different qualities, is well accepted by consumers worldwide [1, 2]. Lychee fruits are used in the preparation of medicinal teas, beverages and food products [3, 4]. In gastronomy, its pulp is used fresh, canned, dried or processed into juices, wines, pickles, jams, ice creams and yogurts [3].

Lychee cultivation in Brazil is still incipient and was initially implemented in the states of São Paulo and Minas Gerais [5, 6] Given the potential for expanding the production and marketing of lychee in Brazil and the influence that the harvest, cultivar, climate, soil type and fertility can have on the nutritional composition of the fruit [7], studies are necessary to evaluate the nutritional values of lychee cultivars grown in Brazil. This information is needed to assess the nutritional adequacy of diets, evaluate the epidemiological relationship between diet and the chemical composition of fruits, and promote research that seeks to improve the nutritional quality of the fruits.

Different cultivars of lychee are produced all around the world. The cultivar Mauritius stands out in South America, the cultivar Groff in the United States and China, and the cultivar Bengal in Brazil [1, 5, 8-11]. Information on the nutritional value, especially vitamins and minerals, of these lychee cultivars is rare in the literature. Furthermore, to date, no information has been published on the nutritional value of the cultivar Tailandes, which is a new lychee cultivar introduced into Brazil and other tropical countries.

The objective of our study was to perform a pioneering characterization of the chemical composition, carotenoids, vitamins and minerals in the pulp of the lychee cultivar Tailandes produced in Brazil, in order to support consumers and producers of fruits during their selection for consumption and cultivation, respectively.

\section{Materials and methods}

\subsection{Acquisition, sampling and preparation of the samples}

Lychee fruits (Litchi chinensis cv. Tailandes) were harvested during harvest season (December-January 2011) in three fruitproducing properties located in the municipality of Ubá (Minas Gerais, Brazil). Each property constituted one repetition, where $500 \mathrm{~g}$ of fruit were collected ( \pm 25 units). After collection, the fruits were transported to the laboratory in Styrofoam boxes no more than $24 \mathrm{~h}$ after harvest. In the laboratory, morphologically perfect fruits at complete maturation (100\% red peel color) were washed in running water and dried on paper towels. Next, the peel, pulp and seeds were manually separated with the aid of a stainless steel knife. After pulping, fresh pulp was homogenized in a domestic food processor (Faet Multipratic, MC5, Brazil), packaged in polyethylene bags and stored in a freezer $\left(-18{ }^{\circ} \mathrm{C} \pm 1{ }^{\circ} \mathrm{C}\right)$ for further analysis.

\subsection{Physical characterization of the fruits}

Individual measurements of the height and diameter of 30 fruits (10 units per repetition) were obtained with the aid of a digital caliper. The fruit (FrM), pulp (PuM), peel (PeM) and seed masses (SeM) were obtained by direct individual weighing on a semi-analytical scale (Gehaka, BG 2000, Brazil). Pulp (PuY), peel (PeY) and seed yields (SeY) were calculated using the equations $\mathrm{PuY}=[(\mathrm{PuM} / \mathrm{FrM}) \times 100], \mathrm{PeY}=[(\mathrm{PeM} /$ $\mathrm{FrM}) \times 100]$ and $\mathrm{SeY}=[(\mathrm{SeM} / \mathrm{FrM}) \times 100]$.

\subsection{Chemical analyses of the fresh pulp}

The titratable acidity, $\mathrm{pH}$, soluble solids [12] and chemical composition [13] of lychee 
pulp were determined in three repetitions. Titratable acidity was determined by volumetric neutralization, using a standard solution of sodium hydroxide $0.1 \mathrm{~mol} \cdot \mathrm{L}^{-1}$. The $\mathrm{pH}$ was determined by direct potentiometry and soluble solids by refractometry, using a portable refractometer (Multibras, M45, Brazil). Moisture was determined by gravimetry after oven drying (Nova Etica, 4000, Brazil) at $105^{\circ} \mathrm{C}$; and the ash was determined by calcination in a muffle furnace (Quimis, Q2342, Brazil) at $550{ }^{\circ} \mathrm{C}$. Protein content was determined by the micro-Kjeldahl method; and total dietary fiber was determined by the gravimetric non-enzymatic method. The lipids were determined by gravimetry after extraction in ethyl ether using a Soxhlet extractor (Eletrothermo, 500WX, Brazil).

Carbohydrates were calculated by difference using the equation: 100 - (\% moisture + $\%$ lipids $+\%$ protein $+\%$ total dietary fiber + $\%$ ash). Total energy was estimated using the conversion factors of $4 \mathrm{kcal} \cdot \mathrm{g}^{-1}$ protein or carbohydrate and $9 \mathrm{kcal} \cdot \mathrm{g}^{-1}$ lipid [14].

\subsection{Determination of carotenoids and vitamins}

During the extraction and analysis of carotenoids and vitamins from lychee pulp, the samples and extracts were protected from light (sunlight and artificial light) using amber glassware, aluminum foil and blackout curtains, and protected from oxygen using jars with lids and a nitrogen gas environment.

The occurrence and content of $\alpha$-carotene, $\beta$-carotene, $\beta$-cryptoxanthin and lycopene were investigated in lychee pulp. Carotenoids were extracted according to Rodriguez-Amaya et al. [15], with modifications. Approximately $5 \mathrm{~g}$ of pulp were added to $20 \mathrm{~mL}$ of cooled acetone, homogenized in a micro-crusher (Marconi, MA 102, Brazil) for 3 min and vacuum-filtered using a Buchner funnel and filter paper. The extraction and filtration procedures were carried out twice more on the residual pulp until complete discoloration of the sample.

Subsequently, the filtrate was transferred in three fractions to a separatory funnel containing $50 \mathrm{~mL}$ of petroleum ether. After the transfer of each fraction, distilled water was added to phase separation (carotenoids in petroleum ether and acetone in water) and the lower phase containing water-acetone was discarded. Anhydrous sodium sulfate was added to the petroleum ether extract to remove any residual water. Subsequently, the extract was concentrated using a rotary evaporator (Tecnal, TE-211, Brazil) at a temperature of $35^{\circ} \mathrm{C} \pm 1{ }^{\circ} \mathrm{C}$, and the volume completed to $10 \mathrm{~mL}$ with petroleum ether.

For analysis, ten $\mathrm{mL}$ of the extract were evaporated using nitrogen gas, and the dry residue was redissolved in $2 \mathrm{~mL}$ of HPLCgrade acetone (Tedia, Brazil). The extracts were filtered through filter units with a porosity of $0.45 \mu \mathrm{m}$ (Millipore, Brazil) and $400 \mu \mathrm{L}$ were injected onto the chromatographic column. Carotenoids were analyzed using a high-performance liquid chromatography system (HPLC) (Shimadzu, SCL 10AT VP, Japan) comprised of a high-pressure pump (Shimadzu, LC-10AT VP, Japan), an autosampler with a loop of $50 \mu \mathrm{L}$ (Shimadzu, SIL-10AF, Japan) and a diode array detector (DAD) (Shimadzu, SPD-M10A, Japan) using the chromatographic conditions developed by Pinheiro-Sant'Ana et al. [16], which included: a HPLC-DAD system with detection at $450 \mathrm{~nm}$, a Phenomenex Gemini RP18 chromatographic column $(250 \mathrm{~mm} \times$ $4.6 \mathrm{~mm}, 5 \mu \mathrm{m})$, fitted with a Phenomenex ODS guard column (C18), $4 \mathrm{~mm} \times 3 \mathrm{~mm}$, and a mobile phase consisting of methanol:ethyl acetate:acetonitrile (70:20:10, v/v/v), with a flow of $1.7 \mathrm{~mL} \cdot \mathrm{min}^{-1}$ and run time of 15 min.

Ascorbic acid (AA) and dehydroascorbic acid (DHA) contents were investigated in lychee pulp. The extraction of these compounds, conversion of DHA to AA and analysis of AA were performed according to Campos et al. [17], with modifications. For extraction, about $5 \mathrm{~g}$ of pulp were ground for $3 \mathrm{~min}$ in $15 \mathrm{~mL}$ of the extraction solution (3\% metaphosphoric acid, 8\% acetic acid, $\mathrm{H}_{2} \mathrm{SO}_{4} 0.3 \mathrm{~N}$ and $1 \mathrm{mM}$ EDTA). The suspension obtained was centrifuged (Fanem, Excelsa Baby II - 206R, Brazil) at $1789 \mathrm{~g}$ (15 min) and vacuum-filtered in a Buchner funnel. Then, the extract was diluted to 
$25 \mathrm{~mL}$ with ultrapure water, centrifuged again at $1789 \mathrm{~g}(15 \mathrm{~min})$ and stored under refrigeration $\left(5^{\circ} \mathrm{C} \pm 1^{\circ} \mathrm{C}\right)$ until the time of analysis.

For conversion of dehydroascorbic acid to ascorbic acid, the extract $(1 \mathrm{~mL})$ was pipetted into an amber flask and $1 \mathrm{~mL}$ of 1.2 M Trizma buffer ( $\mathrm{pH}$ 9.0) containing $40 \mathrm{mM}$ dithiothreitol was added to this. The conversion reaction proceeded for $10 \mathrm{~min}$ at room temperature $\left(22{ }^{\circ} \mathrm{C}\right.$ to $\left.25^{\circ} \mathrm{C}\right)$. Subsequently, the $\mathrm{pH}$ of the extract was reduced to $\mathrm{pH} 2$ by adding $0.9 \mathrm{~mL}$ of $0.4 \mathrm{mM} \mathrm{H}_{2} \mathrm{SO}_{4}$. Analyses of ascorbic acid (AA) were performed from the injection of $100 \mu \mathrm{L}$ of the extracts previously filtered in filter units with a porosity of $0.45 \mu \mathrm{m}$, in the same HPLC system used for analysis of carotenoids. The chromatography conditions described below were used: a RP-18 Lichrospher 100 chromatographic column (250 $\mathrm{mm} \times 4 \mathrm{~mm}, 5 \mu \mathrm{m})$, a HPLC-DAD system, detection at $245 \mathrm{~nm}$, a mobile phase composed of ultrapure water containing $1 \mathrm{mM} \mathrm{NaH}_{2} \mathrm{PO}_{4}, 1 \mathrm{mM}$ EDTA and adjusted to $\mathrm{pH} 3.0$ with $\mathrm{H}_{3} \mathrm{PO}_{4}$; and a mobile phase flow of $1.0 \mathrm{~mL} \cdot \mathrm{min}^{-1}$. The content of dehydroascorbic acid was calculated using the equation: (AA content after conversion - AA content before conversion).

The occurrence and content of the eight components of vitamin $\mathrm{E}(\alpha, \beta, \gamma$ and $\delta$ tocopherols and tocotrienols) were investigated in the lychee pulp. The extraction and analysis procedures were performed in accordance with Pinheiro-Sant'Ana et al. [18], with some modifications. Approximately $5 \mathrm{~g}$ of pulp were added to $4 \mathrm{~mL}$ of heated ultrapure water (about $80^{\circ} \mathrm{C} \pm$ $\left.1{ }^{\circ} \mathrm{C}\right), 10 \mathrm{~mL}$ of isopropanol, $1 \mathrm{~mL}$ of hexane containing $0.05 \%$ of butylhydroxytoluene, $5 \mathrm{~g}$ of anhydrous sodium sulfate and $25 \mathrm{~mL}$ of the extraction solvent mixture (hexane:ethyl acetate, 85:15, v/v). After this procedure, the suspension was homogenized (1 $\mathrm{min}$ ) in a micro-crusher and vacuum-filtered in a Buchner funnel with filter paper. The extraction step was repeated, adding $5 \mathrm{~mL}$ of isopropanol and $30 \mathrm{~mL}$ of the solvent mixture, with subsequent homogenization and vacuum filtration. Then the extract was concentrated in a rotary evaporator (Quimis, Q201, Brazil) at
$70{ }^{\circ} \mathrm{C} \pm 1{ }^{\circ} \mathrm{C}$ and the volume was completed to $25 \mathrm{~mL}$ with the solvent mixture.

After extraction, aliquots of the extract $(5 \mathrm{~mL})$ were dried in nitrogen gas, redissolved in $2 \mathrm{~mL}$ of HPLC-grade hexane and filtered through filter units with a porosity of $0.45 \mu \mathrm{m}$. Analyses of the vitamin E components were performed by injecting $50 \mu \mathrm{L}$ of the a HPLC system (Shimadzu, SCL 10AD VP, Japan) comprising a high-pressure pump (Shimadzu, LC-10AD VP, Japan), an autosampler with a 50- $\mu$ L loop (Shimadzu, SIL-10AF, Japan), a fluorescence detector (Shimadzu, RF10AXL, Japan) and a helium degassing system of the mobile phase (Shimadzu, DGU-2A, Japan). The chromatographic conditions used for analysis included the HPLC system, a fluorescence detector (excitation at $290 \mathrm{~nm}$ and emission at $330 \mathrm{~nm}$ ), a Phenomenex Luna SI100 chromatography column $(250 \mathrm{~mm} \times 4 \mathrm{~mm}$, $5 \mu \mathrm{m})$, a mobile phase comprised of hexane:isopropanol:glacial acetic acid (98.9:0. $6: 0.5, \mathrm{v} / \mathrm{v} / \mathrm{v})$, and a mobile phase flow of $1 \mathrm{~mL} \cdot \mathrm{min}^{-1}$.

The identification of carotenoids and vitamins was performed by comparing the retention times obtained for the standards and the samples analyzed under the same conditions. Furthermore, ascorbic acid was identified by comparison of the absorption spectra for the standard and the peaks of interest in the samples, using the DAD, and the components of vitamin E, by cochromatography.

For quantification of the vitamins, external standardization curves were used, constructed from injection, in duplicate, of six standard solutions with concentrations ranging from (0.0589 to 5.8800) $\mathrm{mg}$ for ascorbic acid; (1.02 to 104.21) ng for $\alpha$-tocopherol; (2.01 to 204.12) ng for $\alpha$-tocotrienol; (2.22 to 107.60) ng for y-tocopherol and (3.21 to 157.60) ng for y-tocotrienol. Thus, there was a linear correlation between the peak areas and the concentrations of each compound injected.

Quantification of the compounds was performed from the calibration curves and regression equations for ascorbic acid ( $y=$ $\left.3277607.19 x-66204.16, \quad R^{2}=0.998\right) ; \alpha-$ tocopherol $(y=76030901.90 x-66102.66$, 


\section{Table I.}

Maximum concentration of elements in standard solution, wavelengths, and limits of detection and quantification for analysis of the pulp composition of lychee cv. Tailandes fruits.

$\begin{array}{lcccc}\text { Element } & \begin{array}{c}\text { Maximum concentration } \\ \text { in standard solution } \\ \left(\mathrm{mg} \cdot \mathrm{L}^{-1}\right)\end{array} & \begin{array}{c}\text { Wavelengths } \\ (\mathrm{nm})\end{array} & \begin{array}{c}\text { Limit of detection } \\ \left(\mu \mathrm{g} \cdot \mathrm{L}^{-1}\right)\end{array} & \begin{array}{c}\text { Limit of quantification } \\ \left(\mu \mathrm{g} \cdot \mathrm{L}^{-1}\right)\end{array} \\ \mathrm{Ca} & 80.0 & 318 & 0.02 & 0.2 \\ \mathrm{Fe} & 2.0 & 260 & 2.00 & 20.0 \\ \mathrm{Mg} & 80.0 & 285 & 0.10 & 1.0 \\ \mathrm{Mn} & 2.0 & 259 & 0.40 & 4.0 \\ \mathrm{Cu} & 1.0 & 225 & 0.40 & 4.0 \\ \mathrm{Zn} & 214 & 1.00 & 10.0 \\ \mathrm{Se} & 1.0 & 196 & 50.00 & 500.0 \\ \mathrm{Mo} & 0.5 & 202 & 3.00 & 30.0 \\ \mathrm{Cr} & 0.5 & 268 & 2.00 & 20.0 \\ \mathrm{P} & 0.5 & 214 & 30.00 & 300.0 \\ \mathrm{~K} & 39.0 & 405 & 20.00 & 200.0 \\ \mathrm{Na} & 100.0 & 3.00 & 30.0 \\ \mathrm{Cd} & 20.0 & 590 & 1.00 & 10.0 \\ \mathrm{Al} & 1.0 & 214 & 3.00 & 30.0 \\ \mathrm{Ni} & 1.0 & 308 & 6.00 & 60.0\end{array}$

$\left.R^{2}=0.999\right) ; \alpha$-tocotrienol $(y=28452328.82 x$ $\left.-105303.68, R^{2}=0.997\right) ; \gamma$-tocopherol $(y=$ $\left.93182765.60 x+170331.40, \quad R^{2}=0.996\right)$; and $\gamma$-tocotrienol $(y=124332948.76 x-$ $\left.300446.44 ; R^{2}=0.997\right)$. The final concentration was obtained by calculations based on the dilutions made.

\subsection{Determination of minerals and trace elements}

Acid digestion of the sample was carried out according to Ekholm et al. [19], using previously demineralized materials and glassware. Approximately $1 \mathrm{~g}$ of the lyophilized sample was transferred to a digestion tube and $10 \mathrm{~mL}$ of nitric acid were added. The mixture was maintained at room temperature for $24 \mathrm{~h}$ and then heated at $50{ }^{\circ} \mathrm{C}$ for $6 \mathrm{~h}$ and $120^{\circ} \mathrm{C}$ for $14 \mathrm{~h}$. The tubes were then cooled to room temperature $\left(22{ }^{\circ} \mathrm{C}\right.$ to $25^{\circ} \mathrm{C}$ ) and the digested solution volume was completed to $25 \mathrm{~mL}$ with deionized water. Three samples of tubes without fruit (blank) were prepared using the same conditions described above.
The contents of minerals and trace elements were analyzed by atomic emission spectrometry with inductively coupled plasma (Optima 3300 DV, Perkin Elmer, U.S.A.). Components in the samples were quantified using an external standard consisting of multi-element standard solutions. Analytical curves were obtained using six solutions with different concentrations. The maximum concentration of elements in the solutions of multi-element standards and the wavelengths $(\mathrm{nm})$ of the samples selected for sample analysis are given (table I).

\subsection{Calculation of the potential of lychee pulp as a source of vitamins and minerals}

Foods can be classified as "sources" of a nutrient when supplying 5\% to $10 \%$ of the Dietary Reference Intake (DRI); as "good sources" when supplying $10 \%$ to $20 \%$ of the DRI, and as "excellent sources" when providing more than $20 \%$ of the DRI [20]. Thus, lychee pulp was classified considering the recommendations of these micronutrients 
Figure 1.

Lychee fruits (Litchi chinensis cv. Tailandes).

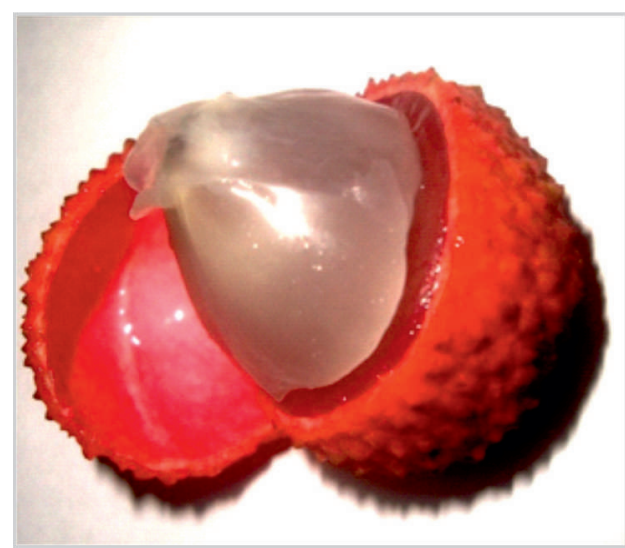

for children between ( 4 and 8) years old, adult males between (19 and 30) years old and pregnant women [21-23].

\subsection{Experimental design and statistical analysis of the data}

Chemical analyses were performed on three repetitions and analyses of carotenoids, vitamins and minerals performed on five repetitions. Descriptive statistics (means, standard deviations and range of parameters) were performed for each parameter. To assess the linearity range of the analytical standards, the peak areas and the concentrations of each compound injected were used for linear regression analysis and to calculate the coefficient of determination $\left(R^{2}\right)$. Statistical analysis was performed using the SAS package (Statistical Analysis System), version 9.2 (2008), licensed for the UFV (Brazil).

\section{Results and discussion}

\subsection{Physical characterization}

Fruits of lychee cv. Tailandes presented a pear shape and rough, reddish peel. Inside, there was a whitish, juicy pulp and rounded dark brown seeds (figure 1).

The coefficient of variation for the dimensions of fruits from cv. Tailandes was low (less than 13.2\%), which showed a high physical uniformity of fruits derived from a commercial cultivation (table II). The mass of fruits from cv. Tailandes was slightly lower to cv. Bengal, which is widely cultivated in Brazil (21 g to $23 \mathrm{~g}$ ) [5, 8]. However, the cultivar analyzed in this study had a higher pulp yield than fruits of $\mathrm{cv}$. Bengal $(50.0 \%-56.0 \%)[5,8]$.

The high pulp yield is an extremely important characteristic for the technological use of lychee by the food industry. It is interesting to note that, although the pulp corresponds to the largest proportion in the entire fruit, the peel and seed together represent a high proportion of the fruit (approximately 40\%). Thus, the use of these fractions, which are usually discarded in the food industry or in other applications, adds value to the fruit.

Despite the small differences among cultivars of lychee (cvs. Tailandes and Bengal) produced in Brazil, it was observed that they have smaller physical characteristics in relation to three cultivars of lychee grown in India and China (cvs. Yu Her Pau, Shahi and China). In these cultivars the following physical characteristics were observed: longitudinal diameter between $3.5 \mathrm{~cm}$ and

Table II.

Physical characteristics of lychee fruits (Litchi chinensis cv. Tailandes) grown in Ubá (Minas Gerais, Brazil).

\begin{tabular}{|c|c|c|c|c|c|c|c|c|c|}
\hline \multirow[t]{2}{*}{ Measure } & Diameter & Length & \multicolumn{4}{|c|}{$\begin{array}{l}\text { Mass } \\
(\mathrm{g})\end{array}$} & \multicolumn{3}{|c|}{$\begin{array}{l}\text { Yield } \\
(\%)\end{array}$} \\
\hline & \multicolumn{2}{|c|}{$(\mathrm{cm})$} & Fruit & Pulp & Bark & Seed & Pulp & Bark & Seed \\
\hline $\begin{array}{l}\text { Mean of } 30 \text { fruits } \\
\pm \text { standard deviation }\end{array}$ & $2.9 \pm 0.1$ & $3.5 \pm 0.2$ & $19.9 \pm 2.2$ & $11.7 \pm 1.2$ & $4.8 \pm 0.6$ & $3.4 \pm 0.3$ & $59.0 \pm 5.7$ & $24.3 \pm 2.0$ & $19.7 \pm 2.6$ \\
\hline Minimum & 2.6 & 3.2 & 13.4 & 9.3 & 3.5 & 0.6 & 51.2 & 20.4 & 3.5 \\
\hline Maximum & 3.1 & 3.9 & 24.5 & 15.8 & 5.8 & 5.3 & 73.3 & 28.8 & 23.4 \\
\hline
\end{tabular}


Table III.

Chemical characteristics and total energy value in lychee (Litchi chinensis cv. Tailandes) grown in Ubá (Minas Gerais, Brazil). Values are expressed in fresh matter. Mean of three repetitions \pm standard deviation.

\begin{tabular}{|c|c|c|c|c|c|c|c|c|c|}
\hline \multirow{2}{*}{$\begin{array}{l}\text { Soluble } \\
\text { solids } \\
\text { ('Brix) }\end{array}$} & \multirow{2}{*}{$\begin{array}{c}\text { Titratable } \\
\text { acidity } \\
(\mathrm{g} \text { citric } \\
\text { acid. } 100 \mathrm{~g}^{-1} \text { ) }\end{array}$} & \multirow[t]{2}{*}{$\mathrm{pH}$} & Moisture & Proteins & Lipids & Ash & $\begin{array}{l}\text { Total dietary } \\
\text { fiber }\end{array}$ & $\begin{array}{c}\text { Available } \\
\text { carbohydrates }\end{array}$ & \multirow{2}{*}{$\begin{array}{l}\text { Total energy } \\
\text { value } \\
\left(\mathrm{kcal} \cdot 100 \mathrm{~g}^{-1}\right)\end{array}$} \\
\hline & & & & & & $\mathrm{g} \cdot 100 \mathrm{~g}$ & & & \\
\hline $17.1 \pm 1.0$ & $0.7 \pm 0.1$ & $4.2 \pm 0.1$ & $80.7 \pm 0.5$ & $0.7 \pm 0.1$ & $0.8 \pm 0.1$ & $0.3 \pm 0.1$ & $2.2 \pm 0.2$ & $15.3 \pm 0.4$ & $70.2 \pm 3.3$ \\
\hline
\end{tabular}

Table IV.

Content of carotenoids and vitamins in lychee (Litchi chinensis cv. Tailandes) grown in Ubá (Minas Gerais, Brazil). Values are expressed in fresh matter. Mean of five repetitions \pm standard deviation.

\begin{tabular}{|c|c|c|c|c|c|c|c|c|}
\hline $\begin{array}{c}\text { Total } \\
\text { carotenoids }\end{array}$ & $\begin{array}{c}\text { Total } \\
\text { vitamin C }\end{array}$ & $\begin{array}{l}\text { Ascorbic } \\
\text { acid }\end{array}$ & $\begin{array}{l}\text { Dehydroascorbic } \\
\text { acid }\end{array}$ & $\begin{array}{c}\text { Total } \\
\text { vitamin } \mathrm{E}\end{array}$ & $\alpha$-tocopherol & $\alpha$-tocotrienol & $\gamma$-tocopherol & $\gamma$-tocotrienol \\
\hline \multicolumn{4}{|c|}{$\left(\mathrm{mg} \cdot 100 \mathrm{~g}^{-1}\right)$} & \multicolumn{5}{|c|}{$\left(\mu \mathrm{g} \cdot 100 \mathrm{~g}^{-1}\right)$} \\
\hline Not detected & $34.7 \pm 7.8$ & $26.9 \pm 1.3$ & $7.8 \pm 0.8$ & $117.0 \pm 2.7$ & $12.8 \pm 0.3$ & $12.6 \pm 1.5$ & $84.7 \pm 1.2$ & $6.8 \pm 0.6$ \\
\hline
\end{tabular}

$3.6 \mathrm{~cm}$, cross-sectional diameter from $3.3 \mathrm{~cm}$ to $3.4 \mathrm{~cm}$, fruit mass between $22.3 \mathrm{~g}$ and $26.0 \mathrm{~g}$, and pulp yield from $60.4 \%$ to $80.0 \%[1,9]$.

\subsection{Chemical characteristics}

The pulp of lychee cv. Tailandes showed high levels of soluble solids and reduced titratable acidity and $\mathrm{pH}$ (table III). These values varied within the ranges observed in Chinese, Indian and Brazilian varieties [1, 8, 9] and corroborated with the sweet taste characteristic of lychee pulp which is highly appreciated by consumers.

Moisture in the pulp of lychee $\mathrm{cv}$. Tailandes was high, which together with rapid darkening of the peel after harvest reduces its shelf life and the commercial value of the fruit [24]. The pulp of the cultivar analyzed had a low content of lipids, proteins and carbohydrates, and hence low total energy. These values resemble the fruit of cv. Bengal [8]. The fruit presented an elevated content of total dietary fiber. A $100-g$ serving of lychee pulp (7-8 units) can be considered a source of dietary fiber by supplying 7.3\% (between 5\% and 10\%) [20] of the recommended dietary fiber for adults $\left(30 \mathrm{~g} \cdot \mathrm{day}^{-1}\right)$ [25].

\subsection{Carotenoids and vitamins}

Lychee pulp presented none of the four carotenoids studied. In contrast, it showed a high vitamin $\mathrm{C}$ content, which was composed of $77.5 \%$ of ascorbic acid and $22.5 \%$ of dehydroascorbic acid (table IV). This content was higher than in cultivars produced in India (cvs. Yu Shahi and China) (17.00-25.00 mg.100 $\mathrm{g}^{-1}$ ) [1], as well as in three cultivars of lychee produced in Hawaii (cvs. Bosworth-3, Groff and Kaimana) (21.00-36.00 mg.100 g ${ }^{-1}$ [10], which showed no dehydroascorbic acid.

Due to the high vitamin C content, which was superior to that of fruits considered a source of this vitamin (orange: $38.2 \mathrm{mg} \cdot 100 \mathrm{~g}^{-1}$; lemon: $31.0 \mathrm{mg} \cdot 100 \mathrm{~g}^{-1}$ ) [26], a serving of the pulp of lychee cv. Tailandes (100 g) may be considered an excellent source of vitamin $\mathrm{C}$ for children ( $4-8$ years old), adult men ( $19-30$ years old) and pregnant women since it provides $138.8 \%, 38.6 \%$ and $46.3 \%$ of the daily recommendations of this vitamin, respectively. 


\begin{tabular}{|c|c|c|c|c|}
\hline \multirow[t]{2}{*}{ Minerals } & \multirow{2}{*}{$\begin{array}{c}\text { Content }^{\mathrm{a}} \\
\left(\mathrm{mg} \cdot 100 \mathrm{~g}^{-1}\right)\end{array}$} & \multicolumn{3}{|c|}{ Intake adequacy $(\%)^{\mathrm{b}}$} \\
\hline & & $\begin{array}{c}\text { Children } \\
\text { (4-8 years old) }\end{array}$ & $\begin{array}{c}\text { Adult men } \\
\text { (19-30 years old) }\end{array}$ & Pregnant women \\
\hline $\mathrm{Ca}$ & $1.80 \pm 0.02$ & 0.22 & 0.18 & 0.18 \\
\hline $\mathrm{Fe}$ & $0.86 \pm 0.01$ & 8.64 & 6.64 & 3.20 \\
\hline $\mathrm{Mg}$ & $12.90 \pm 0.26$ & 9.92 & 3.63 & 3.69 \\
\hline $\mathrm{Mn}$ & $0.06 \pm 0.00$ & 3.93 & 2.88 & 2.95 \\
\hline Se & $0.00 \pm 0.00$ & 0.09 & 0.05 & 0.04 \\
\hline $\mathrm{Cu}$ & $0.12 \pm 0.00$ & 26.44 & 12.93 & 11.63 \\
\hline Mo & $0.002 \pm 0.000$ & - & - & - \\
\hline $\mathrm{Zn}$ & $0.22 \pm 0.00$ & 4.40 & 2.31 & 2.00 \\
\hline $\mathrm{Na}$ & $5.9 \pm 0.09$ & 0.49 & 0.39 & 0.39 \\
\hline $\mathrm{K}$ & $1067.33 \pm 15.01$ & 28.09 & 22.71 & 22.71 \\
\hline $\mathrm{Cr}$ & $0.00 \pm 0.00$ & - & - & - \\
\hline Al & Trace & - & - & - \\
\hline $\mathrm{Cd}$ & $0.00 \pm 0.00$ & - & - & - \\
\hline $\mathrm{Ni}$ & Trace & - & - & - \\
\hline
\end{tabular}

Four components of vitamin E were identified in the pulp of lychee cv. Tailandes, including: $\gamma$-tocopherol: $72.4 \%, \alpha$-tocopherol: $11.0 \%, \alpha$-tocotrienol: $10.8 \%$ and $\gamma$-tocotrienol: $5.9 \%$. Information on the vitamin $\mathrm{E}$ content of lychee pulp is scarce, which reinforces the importance of the current study. Vitamin E content in the pulp of lychee $\mathrm{cv}$. Tailandes was low, and four times lower than that found in lychee pulp produced in Thailand (490 $\left.\mu \mathrm{g} \cdot 100 \mathrm{~g}^{-1}\right)$ [11]. Due to the reduced content, consumption of $100 \mathrm{~g}$ of pulp may contribute little to meeting the recommendations of vitamin $\mathrm{E}$ for children, adult men and women $(0.2 \%, 0.1 \%$ and $0.1 \%$, respectively).

\subsection{Minerals}

The iron content in pulp of lychee cv. Tailandes was approximately $20 \%$ higher than that observed in three cultivars produced in Hawaii (cvs. Bosworth-3, Groff and Kaimana) [10]. The contents of magnesium, manganese and zinc were greater than those found in the Hawaiian cultivars (table V). In contrast, the Hawaiian cultivars showed higher contents of copper, calcium and sodium.

Pulp of lychee cv. Tailandes may be considered a source of iron for men and children and a source of magnesium for children. Furthermore, it was considered a good source of copper for pregnant women and children and an excellent source for adult men, as well as an excellent source of potassium for the three age groups.

Our study is the first to assess the presence and content of selenium, aluminum, nickel, chromium and molybdenum in lychee pulp. The pulp of the lychee cv. Tailandes showed no cadmium and only traces of aluminum and nickel, which suggests that it is safe in relation to consumption of heavy metals. 


\section{Conclusion}

Lychee fruits of the cultivar Tailandes presented high pulp yield and low total energy. The pulp of the fruit was shown to contain different nutrients, vitamins and minerals, being a source of dietary fiber, vitamin C, iron, magnesium, copper and potassium. Furthermore, the pulp presented no cadmium and only traces of aluminum and nickel, which suggests that it is safe in relation to consumption of heavy metals.

\section{Acknowledgments}

The authors acknowledge FAPEMIG (Brazil) for their financial support.

\section{References}

[1] Hajare S.N., Saxena S., Kumar S., Wadhawan S., More V., Mishra B.B., Narayan Parte M., Gautam S., Sharma A., Quality profile of litchi (Litchi chinensis) cultivars from India and effect of radiation processing, Radiat. Phys. Chem. 79 (2010) 994-1004.

[2] Jiang Y., Duan X., Joyce D., Zhang Z., Li J., Advances in understanding of enzymatic browning in harvested litchi fruit, Food Chem. 88 (2004) 443-446.

[3] Wei B., Huang L., Teng J., Jia M., Chemical compositional characterization of ten litchi cultivars, 2011 Int. Conf. on New Technology of Agricultural Engineering (ICAE), Zibo, Chine, 2011.

[4] Chyau C.-C., Ko P.-T., Chang C.-H., Mau J.-L., Free and glycosidically bound aroma compounds in lychee (Litchi chinensis Sonn.), Food Chem. 80 (2003) 387-392.

[5] Lima R.A.Z., Abreu C.M.P. de, Asmar S.A. Corrêa A.D., Santos C.D. de, Embalagens e recobrimento em lichias (Litchi chinensis Sonn.) armazenadas sob condições não controladas, Ciênc. Agrotecnol. 34 (2010) 914-921.

[6] Martins A.B.G., Lichia, Revi. Bras. Frutic. 27 (2005) 1-4.

[7] Lee S.K., Kader A.A., Preharvest and postharvest factors influencing vitamin $\mathrm{C}$ content of horticultural crop, Postharvest Biol. Technol. 20 (2000) 207-220.
[8] Queiroz E. de R., Abreu C.M.P. de, Oliveira K. de S., Constituintes químicos das frações de lichia in natura e submetidas à secagem: potencial nutricional dos subprodutos, Rev. Bras. Frutic. 34 (2012) 1174-1179.

[9] Chang J.-C., Lin T.-S., GA3 increases fruit weight in 'Yu Her Pau' litchi, Sci. Hortic. 108 (2006) 442-443.

[10] Wall M.M., Ascorbic acid and mineral composition of longan (Dimocarpus longan), lychee (Litchi chinensis) and rambutan (Nephelium lappaceum) cultivars grown in Hawaii, J. Food Compos. Anal. 19 (2006) 655-663.

[11] Charoensiri R., Kongkachuichai R., Suknicom S., Sungpuag P., Beta-carotene, lycopene, and alpha-tocopherol contents of selected Thai fruits, Food Chem. 113 (2009) 202-207.

[12] Anon., Normas analíticas do Instituto Adolfo Lutz, Inst. Adolfo Lutz, São Paulo, Brazil, 2005.

[13] Anon., Official methods of analysis of the Association of Official Analytical Chemists, Assoc. Off. Anal. Chem. (AOAC), Wash., D.C., U.S.A., 1998.

[14] Frary C.D., Johnson R.K., Energia, in: Mahan L.K., Escott-Stump S. (Eds.), Krause: alimentos, nutrição e dietoterapia, Rocca, São Paulo, Brazil, 2005.

[15] Rodriguez-Amaya D.B., Raymundo L.C., Lee T.-C., Simpson K.L., Chichester C.O., Carotenoid changes in ripening Momordica charantia, Ann. Bot. 40 (1976) 615-624.

[16] Pinheiro-Sant'Ana H.M., Stringheta P.C., Brandão S.C.C., Azeredo R.M.C., Carotenoid retention and vitamin $A$ value in carrot (Daucus carota L.) prepared by food service, Food Chem. 61 (1998) 145-151.

[17] Campos F.M., Ribeiro S.M.R., Della Lucia C.M., Pinheiro-Sant'Ana H.M., Stringheta P.C., Optimization of methodology to analyze ascorbic and dehydroascorbic acid in vegetables, Quím. Nova 32 (2009) 87-91.

[18] Pinheiro-Sant'Ana H.M., Guinazi M., Oliveira D.d.S., Della Lucia C.M., Reis B.D.L., Brandão S.C.C., Method for simultaneous analysis of eight vitamin $E$ isomers in various foods by high performance liquid chromatography and fluorescence detection, J. Chromatogr. A. 1218 (2011) 8496-8502.

[19] Ekholm P., Reinivuo H., Mattila P., Pakkala H., Koponen J., Happonen A., Hellström J., Ovaskainen M.-L., Changes in the mineral and trace element contents of cereals, fruits 
and vegetables in Finland, J. Food Compos. Anal. 20 (2007) 487-495.

[20] Philippi S.T., Pirâmide dos alimentos: fundamentos básicos da nutrição, Manole, Barueri, Brazil, 2008.

[21] Anon., Reference intakes for thiamin, riboflavin, niacin, vitamin $B 6$, folate, vitamin $B 12$ pantothenic acid, biotin, and choline, U.S Inst. Med., Natl. Acad. Press, Wash., D.C., U.S.A., 1998.

[22] Anon., Dietary Reference Intakes (DRIs): vitamin $\mathrm{A}$, vitamin $\mathrm{K}$, arsenic, boron, cromium, copper, iodine, iron, manganese, molybdenium, nickel, silicon, vanadium and zinc, U.S. Inst. Med., Natl. Acad. Press, Wash., D.C., U.S.A., 2001.
[23] Anon., Dietary reference intakes for vitamin $C$, vitamin $E$, selenium, and carotenoids, U.S. Inst. Med., Natl. Acad. Press, Wash., D.C., U.S.A., 2000.

[24] Neog M., Saikia L., Control of post-harvest pericarp browning of litchi (Litchi chinensis Sonn.), J. Food Sci. Technol. 47 (2010) 100104.

[25] Anon., Dietary reference intakes for energy, carbohydrate, fiber, fat, fatty acids, cholesterol, protein, and amino acids, U.S. Inst. Med., Natl. Acad. Press, Wash., D.C., U.S.A., 2005

[26] Anon., Tabela Brasileira de Composição de Alimentos, Núcleo de Estudos e Pesquisa em Alimentação, NEPA-UNICAMP, Campinas, SP, Brazil, 2011.

\section{Composición química, vitaminas y elementos minerales en el fruto de un nuevo cultivar de lichi (Litchi chinensis cv. Tailandes) explotado en Brasil.}

Resumen - Introducción. En el mundo se producen diferentes cultivares de lichi, pero hasta ahora no se publicó ninguna información sobre el valor nutritivo del cv. Tailandes, nuevo cultivar de lichi introducido en Brasil y en otros países tropicales. Nuestro estudio permitió de evaluar por primera vez las características físicas y químicas, los contenidos de carotenos, vitaminas y minerales de la pulpa del fruto de este cultivar. Material y métodos. La acidez valorable se determinó mediante neutralización volumétrica, el pH mediante potenciometría, los sólidos solubles mediante refractometría, la humedad mediante gravimetría después de secado en horno, el contenido de cenizas mediante calcinación en un horno de mufla, las proteínas mediante el método micro-Kjeldahl, las fibras alimentarias mediante el método gravimétrico no enzimático y los lípidos mediante gravimetría después de extracción con éter etílico. La vitamina C (ácidos ascórbico y dehidroascórbico) y los carotenos ( $\alpha$-caroteno, $\beta$-caroteno, $\beta$-criptoxantina y licopeno) se analizaron mediante cromatografía líquida de alta eficacia (HPLC), la vitamina $\mathrm{E}(\alpha-, \beta-, \gamma$ - y $\delta$-tocoferoles y tocotrienoles) se analizaron mediante HPLC con detección de fluorescencia, y catorce minerales se analizaron mediante espectrometría. Resultados y discusión. Los frutos de lichi $\mathrm{cv}$. Tailandes presentaron un elevado rendimiento de pulpa $(59,1 \%)$, de humedad $\left(80,7 \mathrm{mg} \cdot 100 \mathrm{~g}^{-1}\right)$ y fibras alimentarias $\left(2,2 \mathrm{~g} \cdot 100 \mathrm{~g}^{-1}\right)$. Mostraron un valor energético total flojo $\left(70,2 \mathrm{kcal} \cdot 100 \mathrm{~g}^{-1}\right)$. Estos frutos no mostraron carotenos, pero son una excelente fuente de vitamina $\mathrm{C}\left(34,7 \mathrm{mg} \cdot 100 \mathrm{~g}^{-1}\right)$. El contenido total de vitamina $\mathrm{E}$ fue de $117 \mathrm{~g} \cdot 100 \mathrm{~g}^{-1}$. Los frutos del lichi cv. Tailandes resultan ser una fuente de hierro $\left(0,86 \mathrm{mg} \cdot 100 \mathrm{~g}^{-1}\right)$ y de magnesio $\left(12,90 \mathrm{mg} \cdot 100 \mathrm{~g}^{-1}\right)$, una buena fuente de cobre $\left(0,12 \mathrm{mg} \cdot 100 \mathrm{~g}^{-1}\right)$ y una excelente fuente de potasio $\left(1067,33 \mathrm{mg} \cdot 100 \mathrm{~g}^{-1}\right)$. Conclusión. Los frutos del lichi cv. Tailandes mostraron un elevado rendimiento de pulpa y un valor energético total flojo. La pulpa es una fuente de fibras alimentarias, de vitamina $\mathrm{C}$, de hierro, de magnesio, de cobre y de potasio.

Brasil / Litchi chinensis / frutas / propriedades fisicoquímicas / composición aproxinada / contenido mineral / vitamina C / vitamina $E$ 